\title{
The influence of slowly and rapidly degradable concentrate protein on a number of rumen parameters in dairy cattle
}

\author{
W. A. G. Veen
}

CLO-Institute for Animal Nutrition 'De Schothorst', Meerkoetenweg 26, 8218 NA Lelystad, Netherlands

Received 3 September 1985; accepted 17 January 1986

Key words: concentrate protein, degradability, rumen parameters, $\mathrm{pH}$, ammonia, volatile fatty acids, lactate

\begin{abstract}
In the course of five trials we traced the effects on various rumen parameters of concentrates with rapidly and slowly fermentable protein. Samples of rumen fluid were taken directly before the concentrate was fed in the morning, and again after 45, 90 and 135 minutes and sometimes after 180 minutes. In all samples the $\mathrm{pH}$ and the total concentration of ammonia $\left(\mathrm{NH}_{3}+\mathrm{NH}_{4}^{+}\right)$were determined. In several trials the concentration of volatile fatty acids and that of $\mathrm{D}$ - and L-lactate were also determined. For purposes of the latter determination extra samples of rumen fluid were occasionally taken after 30 and 60 minutes.

The ingredients on which the trial concentrates were based all contained crude protein that was of itself more or less easily fermentable in the rumen. Only one trial involved a formaldehyde-treated ingredient. The cows received the concentrates during successive periods of 14 days each, the last two days being reserved for the sampling of the rumen fluid.

On the whole the $\mathrm{pH}$ after a concentrate feed was not significantly affected by differences in protein degradability.

The concentration of ammonia was on average higher when concentrates with easily fermentable protein were fed. The peak concentration, varied from 10 to $12.5 \mathrm{mmol} / \mathrm{l}$. On slowly fermentable protein peak concentration varied between 4 and $8 \mathrm{mmol} / \mathrm{l}$.

The maximum concentration of lactate, was not influenced by the degradability of the protein. The maximum concentration of L-lactate ranged from 2 to $6 \mathrm{mmol} / \mathrm{l}$, and that of D-lactate from 4 to $7 \mathrm{mmol} / \mathrm{l}$.

After the concentrate with easily degradable protein was fed, the concentration of volatile fatty acids rose more rapidly than when the concentrate contained slowly degradable protein. At all sampling times the molar acetate/propionate ratio was higher when slowly degradable protein was fed. The possible cause of this phenomenon is discussed.
\end{abstract}




\section{Introduction}

Since 1975 'De Schothorst' has carried out a number of trials involving lactating cows and heifers which were designed to study the effect of concentrates with slowly fermentable protein on milk production and milk composition. Summaries of these trials have appeared in the annual reports of 'De Schothorst' (Bakker et al., $1977,1980,1981,1982,1983,1984)$. Differences in the level of rapidly fermentable, slowly fermentable and rumen undegradable protein can be produced by a careful selection of protein-rich ingredients for the concentrate (Majdoub et al., 1978; Oldham et al., 1979a; Grummer \& Clark, 1980; Wilson \& Strachan, 1980; Ørskov et al., 1981; Dennison \& Phillips, 1982; Baxter et al., 1983; Erdman \& Vandersall, 1983).

Often protein-rich ingredients treated with formaldehyde are used, in which case the protein passes almost undegraded through the rumen (Verité \& Journet, 1977; Kaufmann \& Lüpping, 1979; Folman et al., 1981; Kaufmann et al., 1982; Rae et al., 1983). Only in one of the trials carried out at 'De Schothorst' a formaldehydetreated ingredient was used. In all trials slow degradability of the concentrate protein in the rumen resulted in higher milk production and a higher milk fat content at the beginning of lactation.

The increased milk production may have been due to the effect of protein or amino acids on the energy status of the cows (Oldham, 1980). The increase in the fat content of the milk may have been the result of a higher acetate/propionate ratio in the rumen. A favourable ratio of acetate to propionate after feeding can be maintained if sufficient ammonia is constantly present for the cellulolytic bacteria (Phipps et al., 1981). The processes by which the fat is transported through the blood from the fatty tissues to the udder may also be affected by the ration protein. Fat is transported through the blood in the form of lipoproteins and the amino acid methionine plays a key role in the process. It is necessary for the synthesis of serum lipoproteins, it is a methyl donor for phospholipids and it has a special function in the bonding of the lipid and the protein portions of the lipoproteins (McCarthy et al., 1968). In addition, it is assumed that methionine promotes the synthesis of fat in the udder (Rémond et al., 1971), and that the protein level in the ration affects the transfer of blood lipids from carrier proteins to the udder (Oldham et al., 1979b).

The trials described here deal with the influence of protein degradability on various rumen parameters. The effect on blood parameters will be described in a later publication.

\section{Materials and methods}

The cows were Dutch Friesians or cross-breeds of Dutch Friesians and Holstein Friesians. The rumen-fistulated cows were given the same experimental treatments as the cows in the feeding trials referred to in the introduction, except that the various concentrates were fed during successive periods.

In all trials the cows were fed according to the norm for digestible crude protein (dcp) supply and slightly above the norm for VEM (Dutch feed unit for dairy cows) 
supply. The norms were set by the Centraal Veevoederbureau in the Netherlands. The roughage contained $1.5 \mathrm{~kg}$ dry matter per $100 \mathrm{~kg}$ body weight, and consisted of prewilted grass silage or a combination of prewilted grass silage and maize silage given separately. However the roughage was fed before sampling only in trials RM-

Table 1. Composition of the concentrates.

\begin{tabular}{|c|c|c|c|c|c|c|c|c|c|}
\hline & \multicolumn{2}{|c|}{ RM-A 15} & \multicolumn{3}{|c|}{ RM-A18 } & \multicolumn{2}{|c|}{$\mathrm{RM}-\mathrm{B} 20 / 21$} & \multicolumn{2}{|c|}{ RM-B22 } \\
\hline & $\mathrm{b}^{1}$ & $\mathrm{~B}^{2}$ & $b$ & B & $\mathrm{B}^{1}$ & $\mathbf{b}$ & B & $\mathrm{b}$ & B \\
\hline Maize & - & 20.40 & 15.00 & 30.25 & 35.00 & - & 8.00 & - & - \\
\hline Rye & 22.50 & - & - & - & - & - & - & - & - \\
\hline Wheat & 20.00 & - & - & - & - & - & - & - & - \\
\hline Lupin & - & - & - & - & - & - & - & 25.00 & - \\
\hline Horsebeans & - & - & 8.00 & - & - & 10.00 & - & - & - \\
\hline Potato pulp, dried & - & 17.50 & - & - & - & - & - & - & - \\
\hline Maize gluten meal & - & 11.00 & - & 5.00 & - & - & 12.00 & - & 11.67 \\
\hline Maize gluten feed & - & - & 10.00 & - & - & 13.00 & - & 3.00 & 4.33 \\
\hline Beet pulp, dried & - & - & 18.00 & 25.00 & 25.00 & 20.00 & 20.00 & 10.00 & 10.00 \\
\hline Molasses, cane & 5.00 & 5.00 & 5.00 & 5.00 & 5.00 & 5.00 & 5.00 & 6.00 & 6.00 \\
\hline Breweries grains, dried & - & 5.00 & - & 5.00 & - & - & 16.70 & - & 27.53 \\
\hline Malt sprouts & 15.00 & - & - & - & - & 8.70 & - & - & - \\
\hline Citrus pulp, dried & - & - & 10.00 & - & - & 20.00 & 20.00 & 30.00 & 30.00 \\
\hline Tapioca meal & 4.80 & 12.00 & 20.00 & 15.00 & 12.40 & 4.10 & 13.80 & 0.67 & - \\
\hline Soya beans & - & - & - & - & - & 2.40 & - & - & - \\
\hline Soya beans, heat treated & - & - & - & - & - & - & 2.00 & - & 2.50 \\
\hline Babassu meal, solv. extr. & - & - & - & 4.00 & - & - & - & - & - \\
\hline Groundnut meal, solv. extr. & 14.60 & - & - & - & - & - & - & 10.00 & - \\
\hline Coconut expeller & - & 6.00 & - & 5.00 & 4.00 & - & - & - & - \\
\hline Rape seed meal, solv. extr. & - & 6.00 & - & - & - & - & - & 13.33 & - \\
\hline Linseed expeller & 15.00 & - & 6.00 & - & - & 15.00 & - & - & - \\
\hline Sesame expeller & - & - & 6.00 & - & - & - & - & - & - \\
\hline Soya bean meal, solv. extr. & - & 14.50 & - & 3.00 & - & - & - & - & 6.00 \\
\hline Protane $S^{3}$ & - & - & - & - & 16.00 & - & - & - & - \\
\hline Renderers fat & 0.60 & - & - & - & - & - & - & - & - \\
\hline $\mathrm{CaHPO}_{4}$ & - & 0.60 & 0.75 & 1.25 & 1.25 & 0.50 & 1.20 & 0.70 & 0.67 \\
\hline Salt & 0.75 & 0.75 & 0.75 & 0.75 & 0.75 & 0.80 & 0.80 & 0.80 & 0.80 \\
\hline Limestone & 1.25 & 0.75 & - & 0.25 & 0.10 & - & - & - & - \\
\hline Vitamins/minerals concentrate & 0.50 & 0.50 & 0.50 & 0.50 & 0.50 & 0.50 & 0.50 & 0.50 & 0.50 \\
\hline $\mathrm{VEM}^{7}$, calculated & 958 & 957 & 943 & 940 & 937 & 939 & 940 & 939 & 939 \\
\hline dcp, calculated g/kg & 171 & 171 & 96 & 96 & 96 & 124 & 124 & 170 & 170 \\
\hline Protein solubility, $\%^{4}$ & 40 & 12 & 42 & 13 & 11 & 42 & 12 & 49 & 11 \\
\hline Protein degradability ${ }^{5}$ & n.d. ${ }^{6}$ & n.d. & n.d. & n.d. & n.d. & 54 & 15 & 73 & 35 \\
\hline $\mathrm{cp}$, determined $\mathrm{g} / \mathrm{kg}$ & 204 & 206 & 130 & 133 & 130 & 160 & 165 & 200 & 216 \\
\hline Starch + sugars, calculated $\mathrm{g} / \mathrm{kg}$ & 370 & 378 & 370 & 378 & 396 & 232 & 268 & 184 & 164 \\
\hline \multicolumn{10}{|c|}{$\begin{array}{l}1 \mathrm{~b}=\text { easily fermentable protein. } \\
2 \mathrm{~B}=\text { slowly fermentable protein. } \\
50 \% \text { soya bean meal, } 50 \% \text { rape seed meal (solv. extr.) formaldehyde-treated, Ucanor, France. } \\
4 \text { In mineral buffer solution, according to Crooker et al. (1978). } \\
5 \text { After } 12 \mathrm{~h} \text {. incubation in nylon bag in rumen. }\end{array}$} \\
\hline
\end{tabular}


A15 and RM-A18. In the other trials roughage was not given until after sampling had taken place.

The composition of the concentrates used is given in Table 1. The solubility in vitro of the concentrate protein was determined according to Wohlt et al. (1973), with the modification according to Crooker et al. (1978).

\section{Trial RM-A15}

Four cows were divided into two pairs, and during successive periods of 14 days they were given concentrates containing protein of relatively high solubility $(40 \%)$ or relatively low solubility ( $12 \%$ ). The trial consisted of 4 periods, so that each cow received each of the two concentrates during two periods of 14 days each.

At the beginning of the experiment two of the cows were in the 5th week of lactation, one in the 14th and one in the 20th.

At $07 \mathrm{~h} 00$ maize silage was fed. At $08 \mathrm{~h} 00$ on the last two days of each 14-day period a sample of rumen fluid was taken, after which 5 to $6 \mathrm{~kg}$ concentrate was fed. Then three more samples of rumen fluid were taken, at intervals of 45 minutes.

\section{Trial RM-A18}

Four cows in different stages of lactation were given 4 different concentrates according to a $4 \times 4$ Latin square design. Concentrate $b$ had a protein solubility of $42 \%$ and concentrate $B$ of $13 \%$. Concentrate $B^{\prime}$ had a protein solubility of $11 \%$, but contained $16 \%$ combined soya bean oil meal and rape-seed oil meal which had been treated with formaldehyde. The fourth experimental treatment $b^{\prime}$ consisted of concentrate $\mathrm{b}$, supplemented with the calcium salt of $\mathrm{N}$-hydroxymethylmethionine (HMM-Ca, manufacturer Degussa, Wolfgang, West Germany). This preparation contained $70 \%$ dl-methionine. The cows were given 12 or $24 \mathrm{~g}$ dl-methionine per day, depending on whether they were receiving more or less than $9 \mathrm{~kg}$ concentrates per day. The rumen fluid was sampled on two consecutive days at the end of each experimental period. At $07 \mathrm{~h} 30$ the cows received prewilted grass silage and at $08 \mathrm{~h} 30$ the concentrate. A rumen sample fluid was taken just before the morning feeding, and again 45, 90 and 135 minutes later.

\section{Trial $R M-B 20$}

In this trial two concentrates were fed to two cows which at the beginning of the trial were in the 6th and 7 th week of lactation, respectively. The concentrates were given during four 14-day periods, as in trial RM-A15. The sampling time was extended to 180 minutes. For the determination of lactate concentration several samples were also taken after 30 and 60 minutes. After 12 hours of incubation in nylon bags in the rumen the protein degradability percentage of the concentrates was found to be $54 \%$ (b) and $17 \%$ (B). The protein solubility was $42 \%$ and $12 \%$, respectively.

\section{Trial RM-B21}

In this trial the same concentrates were used as in trial RM-B20. However an additional concentrate was fed which consisted of ration b plus $570 \mathrm{mg}$ niacin per kilo- 
gram $\left(b^{\prime}\right)$. The trial involved five fistulated cows. Up to the 4th week of lactation these cows received concentrate $b$, from the 4 th to the 6 th week concentrate $b^{\prime}$, from the 6 th to the 8 th week concentrate $b$, and from the 8 th to the 10 th week concentrate $B$. By repeating treatment $b$ later on in the trial it was possible to ascertain whether the stage of lactation had any effect on the composition of the rumen fluid. Sampling was as in trial RM-B20, except that an extra sample was taken 30 minutes after the concentrate was fed, for the determination of the D- and L-lactate.

\section{Trial RM-B22}

Four animals were used in the trial; two received a feed containing slowly degradable protein and the other two a feed with rapidly degradable protein. The first samples were taken in the 5th week of lactation; then the concentrate was changed and the second sampling was in the 9 th week of lactation. The concentrates used had a protein degradability after 12 hours of incubation in the rumen of $70 \%$ and $35 \%$, respectively.

In the rumen fluid samples from RM-A15 and RM-A18 only the $\mathrm{pH}$ and the ammonia concentrations were determined. In the samples from RM-B20, RM-B21 and RM-B22 the concentration of volatile fatty acids was also determined, and in RM-B20 and RM-B21 the concentration of D- and L-lactate as well. In the latter three trials the cows were not allowed to drink during the sampling period. Directly before sampling the rumen fluid a tube of about $1 \mathrm{~m}$ long was inserted through the structural layer of the rumen, ending near the ventral sac. The end of the tube was stoppered and it was perforated all round over a length 0 samples were taken by means of a length of plastic tubing fitted to a syringe. The $\mathrm{pH}$ of the fluid was measured directly.

In the laboratory $5 \mathrm{ml}$ rumen fluid was then mixed with $1 \mathrm{ml}$ of a $60 \%$ solution of trichloro-acetic acid. After 10 minutes of centrifugation, $2 \times 1 \mathrm{ml}$ clear liquid was taken for a duplo determination of total ammonia $\left(\mathrm{NH}_{3}+\mathrm{NH}_{4}^{+}\right)$according to the Conway method. After 30 and 60 minutes extra samples were taken from a number of cows involved in trials RM-B20 and RM-B21, for the enzymatic determination of D- and L-lactate. For this determination $3 \mathrm{ml}$ rumen fluid was mixed with $3 \mathrm{ml}$ of a $5 \%$ solution of zinc sulphate, after which the mixture was centrifuged. D- and Llactate were oxidized to pyruvate with NAD and D- and L-lactate dehydrogenase respectively. The NADH thus formed was determined spectrophotometrically at $334 \mathrm{~nm}$. Approximately $100 \mathrm{ml}$ rumen fluid was mixed with $1 \mathrm{ml}$ of a saturated solution of mercuri(II)chloride and stored at $-20{ }^{\circ} \mathrm{C}$, for a subsequent analysis of the volatile fatty acids. After thawing and thorough homogenization $5 \mathrm{ml}$ rumen fluid was combined with $1 \mathrm{ml}$ of a solution with an internal standard. This solution consisted of $2.5 \mathrm{~g}$ pivalic acid dissolved in $250 \mathrm{ml} 5 \%$ solution of ortho-phosphoric acid. After centrifugation a sample of the clear fluid was taken for gas chromatographic analysis on a packed column of $3 \%$ Carbowax $20 \mathrm{M}$ and $0.5 \%$ phosphoric acid on Carbopack B, 60-80 mesh.

The response factors of the volatile fatty acids were determined with the aid of a standard mixture of volatile fatty acids and pivalic acid. 


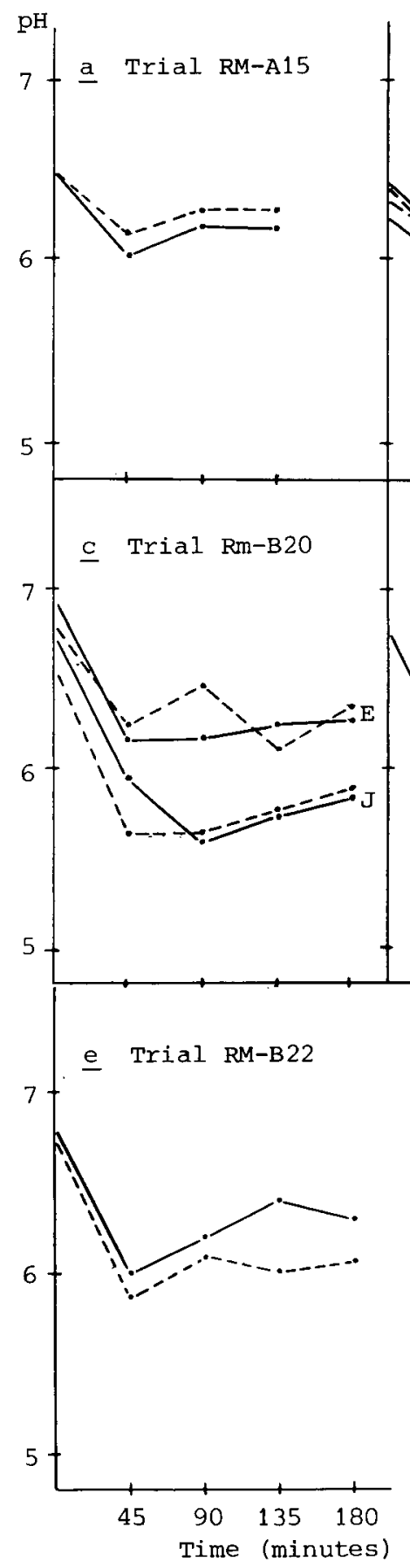

b Trial RM-A18 


\section{Results}

The inclusion of niacin in one of the feeds in trial RM-B21 had no effect on the rumen parameters. For this reason the results of this experimental treatment are not included in the figures.

\section{$p H$}

Fig. 1a, 1b, 1c, 1d and 1e give the course of the $\mathrm{pH}$ variations of the rumen fluid in relation to the time of sampling. Because the stage of lactation had no significant effect on the $\mathrm{pH}$ level, as shown by the results of trial RM-B21, and because the differences between the animals and between two successive days were generally smaller than the differences between the various treatments, all values are given as averages, with the exception of those of trial RM-B20. There the difference between the two animals was striking. Cow Elze 64 consumed the concentrate very slowly, and this is clearly reflected in a less marked decline in the $\mathrm{pH}$ level after a feed of either concentrate.

The $\mathrm{pH}$ variations corresponded to a quadratic function. The curves for the experimental treatments with rapidly and slowly degradable protein ran more or less parallel. Trial RM-B22 was the only one in which the average $\mathrm{pH}$ level for all sampling times was clearly lower for the treatment with rapidly degradable protein. The results of trial RM-A18 show that at all sampling times the $\mathrm{pH}$ was on average highest for the experimental treatment in which the concentrate was pre-treated with formaldehyde $\left(\mathrm{B}^{\prime}\right)$. There were no statistically significant differences between the other treatments. In trial RM-A15, on the other hand, the $\mathrm{pH}$ after feeding was lower for the concentrate with slowly degradable protein.

\section{Ammonia concentration}

Fig. $2 \mathrm{a}, 2 \mathrm{~b}, 2 \mathrm{c}, 2 \mathrm{~d}$ and $2 \mathrm{e}$ show the variations in the concentration of ammonia $\left(\mathrm{NH}_{3}\right.$ $+\mathrm{NH}_{4}^{+}$) in the rumen fluid. In all trials, at all the sampling times after feeding, a higher concentration of ammonia was found to be present on the treatment with rapidly degradable concentrate protein. The only exception was trial RM-A18, where the difference with slowly degradable concentrate protein was less marked. The peak in ammonia concentration always occurred after 45 or 90 minutes. On the treatment containing slowly degradable protein the increase in the concentration between 0 and 45 or 90 minutes was smaller than for the treatment containing rapidly degradable protein.

The slow feed intake of cow Elze 64 in trial RM-B20 had no effect on the course of the ammonia concentration when the slowly degradable concentrate protein was fed, though it did affect the results recorded for rapidly fermentable protein (Fig. 2c).

The addition of N-hydroxymethyl-methionine in trial RM-A18 did not affect the variations in ammonia concentration. The latter was, however, somewhat lower when a concentrate with slowly degradable protein was fed which contained a formaldehyde-treated ingredient (Protane S; see Table 1). 
W. A. G. VEEN

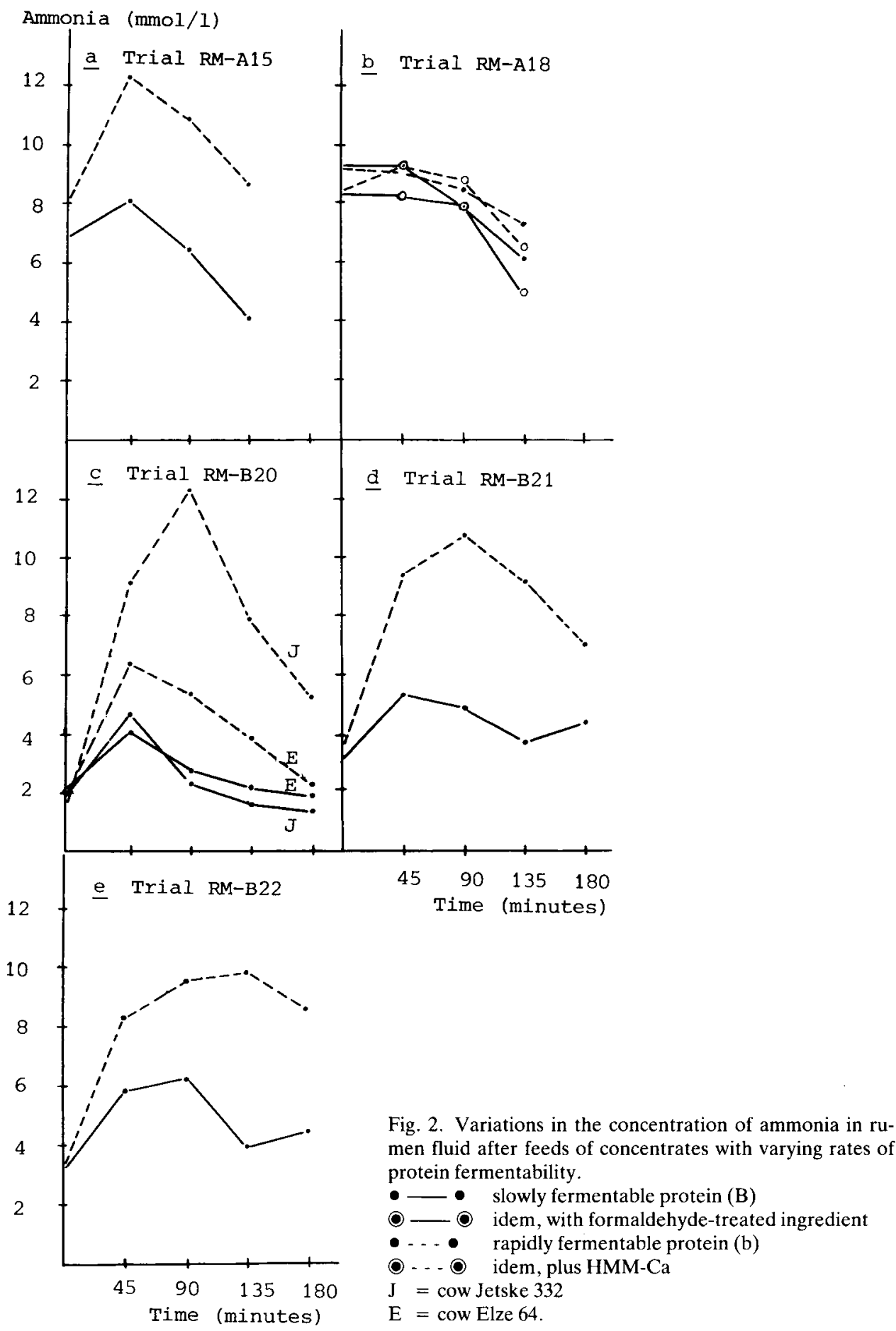




\section{Lactate concentration}

Fig. 3a, 3b, 3c and 3d show the variation in D- and L-lactate concentration for trials RM-B20 and RM-B21. In neither case did the degree of degradability of the concentrate protein affect the course of the curve. Both L- and D-lactate attained maximum concentration quite quickly, 30-45 minutes after the concentrate was fed.

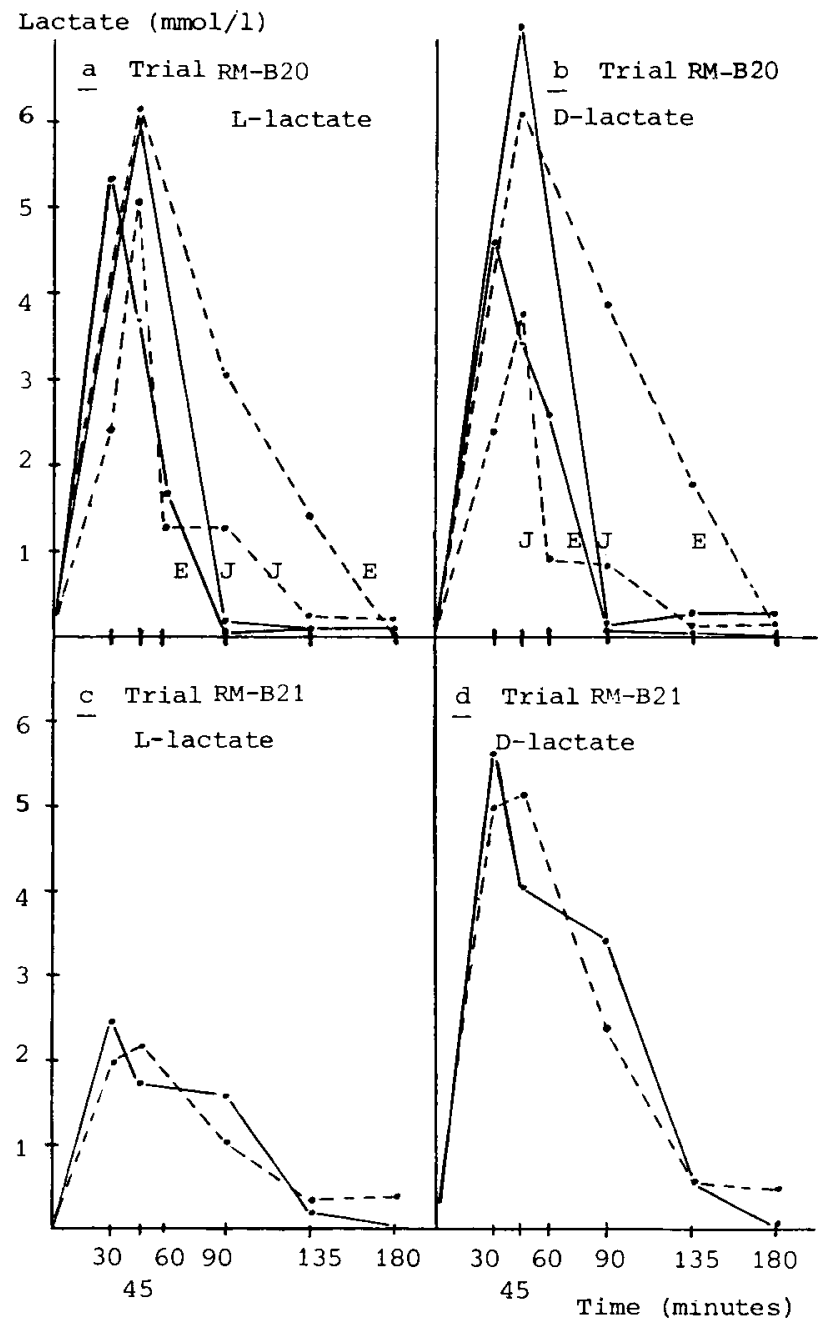

Fig. 3. Variations in the concentration of $\mathrm{D}$ - and L-lactate in rumen fluid after feeds of concentrates with varying rates of protein fermentability.

- - slowly fermentable protein (B)

- . - rapidly fermentable protein (b)

$\mathrm{J}=$ cow Jetske 332

$\mathrm{E}=$ cow Elze 64 . 
Three hours after the concentrate was fed there was almost no lactate left in the rumen. The maximum concentration of D-lactate was on average somewhat higher than that of L-lactate. However this was due largely to the results of trial RM-B21.

\section{Volatile fatty acid concentration}

Fig. $4 \mathrm{a}, 4 \mathrm{~b}, 4 \mathrm{c}$ and $4 \mathrm{~d}$ show the variations in the concentration of acetic acid, pro-

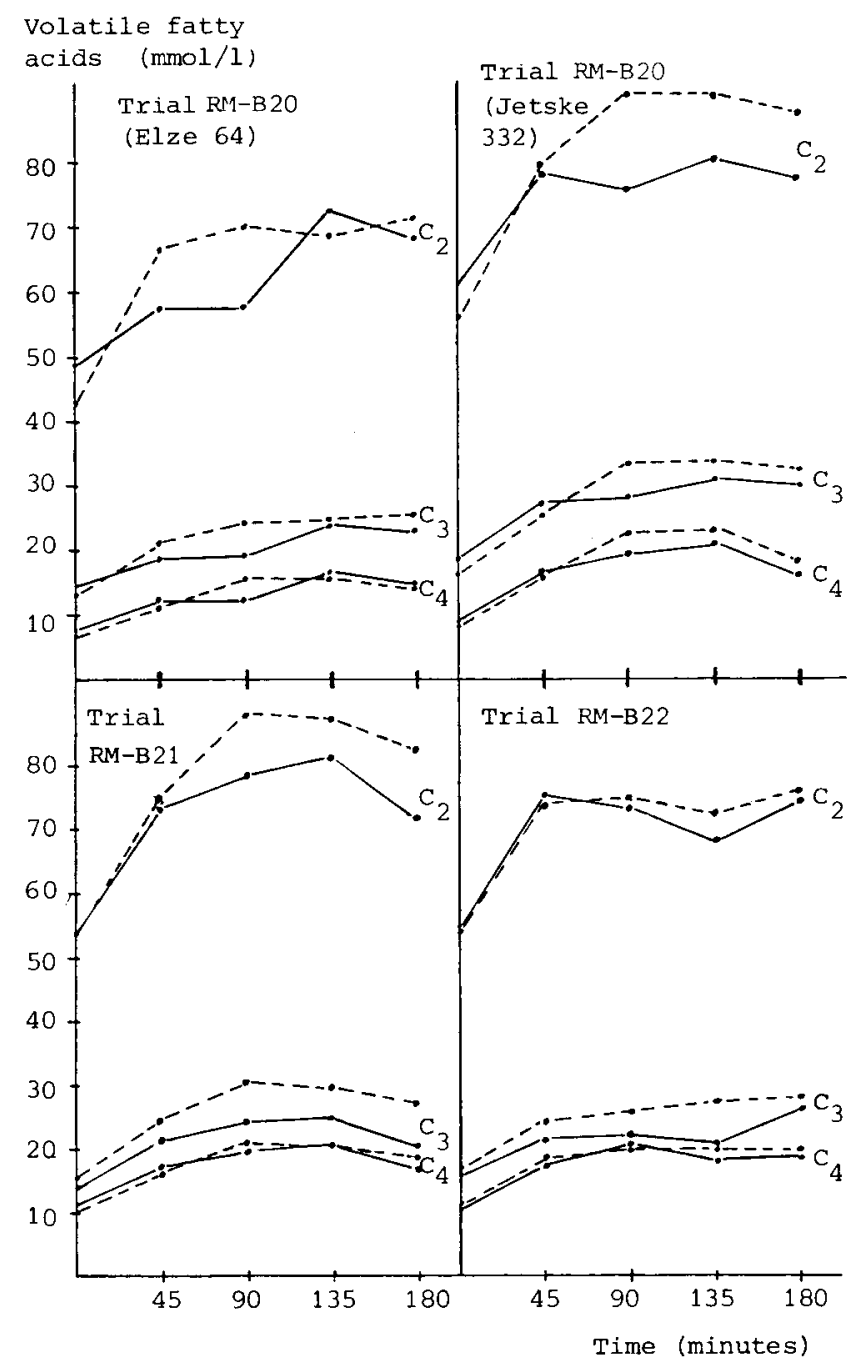

Fig. 4. Variations in the concentrations of acetic acid $\left(C_{2}\right)$, propionic acid $\left(C_{3}\right)$ and butyric acid $\left(C_{4}\right)$ in rumen fluid after feeds of concentrates with varying rates of protein fermentability.

- - slowly fermentable protein (B)

-... rapidly fermentable protein (b). 
pionic acid and butyric acid for cows Elze 64 and Jetske 332 in trial RM-B20, and the average values for all the cows involved in trials RM-B21 and RM-B22.

The curves show that after the concentrate with rapidly degradable protein was fed the concentration of all volatile fatty acids in the rumen fluid rose more sharply than when the animals received a concentrate with slowly degradable protein, although in the case of butyric acid this only held true for cow Jetske 332 in trial RMB20. In trial RM-B21 the differences in the concentration of acetic acid and propionic acid between treatments were on average statistically significant at all sampling times $(P<0.01)$. Expressed in substance concentration (molar) ratios, significantly more acetic acid and butyric acid and less propionic acid were found when the treatment contained slowly degradable concentrate protein.

Table 2 gives the concentration of the sum of all the volatile fatty acids, while

Table 2. Concentration of volatile fatty acids in rumen fluid after feeding concentrate protein with varying rates of degradability $(\mathrm{mmol} / \mathrm{l})$.

\begin{tabular}{cccccccc}
\hline & \multicolumn{2}{l}{ Time (minutes) } & & & & Statistical \\
\cline { 2 - 5 } & 0 & 45 & 90 & 135 & 180 & average & \\
significance
\end{tabular}

${ }^{1} \mathrm{~b}=$ rapidly degradable protein.

${ }^{2} \mathrm{~B}=$ slowly degradable protein.

Table 3. Substance concentration (molar) ratio acetate/propionate in rumen fluid after feeding concentrate proteins with varying rates of degradability.

\begin{tabular}{|c|c|c|c|c|c|c|c|}
\hline & \multicolumn{6}{|c|}{ Time (minutes) } & \multirow{2}{*}{$\begin{array}{l}\text { Statistical } \\
\text { significance }\end{array}$} \\
\hline & 0 & 45 & 90 & 135 & 180 & average & \\
\hline \multicolumn{8}{|c|}{ RM-B20 } \\
\hline$b^{1}$ & 3.35 & 3.14 & 2.80 & 2.73 & 2.76 & 2.96 & \multirow[t]{2}{*}{ n.s. } \\
\hline $\mathbf{B}^{2}$ & 3.35 & 2.96 & 2.85 & 2.80 & 2.81 & 2.95 & \\
\hline \multicolumn{8}{|c|}{ RM-B21 } \\
\hline b & 3.62 & 3.11 & 2.89 & 3.00 & 3.10 & 3.12 & \multirow[t]{2}{*}{$P<0.01$} \\
\hline B & 4.00 & 3.47 & 3.29 & 3.37 & 3.57 & 3.54 & \\
\hline \multicolumn{8}{|c|}{ RM-B22 } \\
\hline $\mathrm{b}$ & 3.18 & 3.06 & 2.92 & 2.74 & 2.80 & 2.94 & \multirow[t]{2}{*}{$P<0.01$} \\
\hline B & 3.64 & 3.51 & 3.33 & 3.31 & 3.18 & 3.40 & \\
\hline
\end{tabular}

${ }^{1} \mathrm{~b}=$ rapidly degradable protein.

$2 \mathrm{~B}=$ slowly degradable protein. 
Table 3 shows the molar ratio between acetic acid and propionic acid.

The concentration of all volatile fatty acids taken together clearly tends to be higher for a concentrate with rapidly degradable protein than for one with slowly degradable protein. In trial RM-B20 this difference was less marked for cow Elze 64 , whose feed intake was noticeably slow. The largest difference in concentration occurred $1 \frac{1}{2}$ hours or more after the concentrate was fed.

As was expected, the individual differences were fairly big, although care was taken to ensure that the cows did not influence the concentration of volatile fatty acids by consuming large quantities of water.

The ratio acetate/propionate was significantly higher after the concentrate with slowly degradable protein was fed, except in trial RM-B20, where the differences were not statistically significant.

\section{Discussion}

The exact spot in the rumen at which samples were taken could not be determined, but this was in all probability the ventral sac. The important thing is that the perforated tube was inserted in all the experimental animals at more or less the same angle, and that it penetrated the structural layer. According to Mahadevan et al. (1982) the $\mathrm{pH}$ and the concentration of ammonia and volatile fatty acids follow a cyclical course. Thus in comparing the effects of the various feeds, there is no point in considering the values registered at any one particular point in time. In order to demonstrate the statistical differences between the various rations, we have, however, in several cases made use of the average values of the observations recorded at various times.

$p H$

In trials RM-A15 and RM-A18 the first measured $\mathrm{pH}$ was lower than in the other trials, but it declined less sharply in the first 45 minutes after a concentrate was fed. The difference between these trials and the others was that here the cows had been given roughage 1 to $1 \frac{1 / 2}{2}$ hours before the first sampling. As a result volatile fatty acids were produced from the rapidly fermentable carbohydrates and proteins contained in the maize silage or prewilted grass silage. It was only in trial RM-B22 that during the entire observation period the $\mathrm{pH}$ was significantly lower for the concentrate with rapidly degradable protein. In this trial the concentrate with rapidly degradable protein also contained somewhat more soluble carbohydrates than the feed with slowly degradable protein. In trials RM-B20 and RM-B21 the opposite was true (Table 1). However it seems unlikely that these small differences had any significant effect on the rumen fermentation. Thus it can reasonably be concluded that the considerable differences in the level of rapidly fermentable proteins in the concentrate had no significant effect on the $\mathrm{pH}$ variations in the rumen fluid. This is in agreement with Kung et al. (1983). The negligible effect of the experimental feeds on the $\mathrm{pH}$ variation can be explained by the fact that shortly after feeding the variations in the concentration of ammonia and volatile fatty acids run more or less parallel (Figs. 2, 4), while the effect of lactate is extremely short-lived (Fig. 3). 
A factor which had a far more significant effect on the $\mathrm{pH}$ variations was the rate of feed intake of the individual cow, as shown in Fig. 1c. Cow Elze 64 ate very slowly and had often finished only one-half to three-fourths of the feed when the last sampling took place, three hours after feeding. The differences in $\mathrm{pH}$ level between the cows Elze 64 and Jetske 332 was of the order of those found by Malestein et al. (1981) when concentrates were fed in 3 portions of $4 \mathrm{~kg}$, as opposed to two portions of $6 \mathrm{~kg}$ each.

On all treatments the $\mathrm{pH}$ level remained below 6.5 , the optimum level for the cellulolytic bacteria, for the full three hours after feeding. Thus it can be concluded that the breakdown of roughage does not really get under way until after that threehour period.

In general the $\mathrm{pH}$ was higher immediately before the morning feed than afterwards. One possible explanation is the fact that before feeding there is no easily fermentable substrate remaining in the rumen. Another explanation may be the fact that it is precisely in the hours before the morning feed that the concentration of ammonia rises, through the endogenous metabolism of bacteria and/or through lysis of bacteria (Wohlt et al., 1976a). In our experiments the concentration of ammonia immediately before the morning feed was sometimes higher than or level with that registered after 180 minutes (Fig. 2). In addition, the concentration of ammonia may increase again many hours after feeding, as a result of increased salivary secretion (Wohlt et al., 1976a).

\section{Ammonia}

The difference in the rate of fermentation of the concentrate protein was most clearly illustrated by the concentration of ammonia in the rumen fluid (Fig. 2). The peak in concentration came at approximately the same time on both treatments, namely 45 to 90 minutes after the concentrate was fed. Only trial RM-A18 showed no peak in the concentration of ammonia. In this trial the cows had been given half their daily portion of prewilted grass silage an hour before the concentrate was fed. Approximately $50 \%$ of the crude protein from prewilted grass silage is soluble in vitro and degradable within one hour with the nylon bag technique (Veen, 1984). This naturally leads to a rapid increase in the concentration of ammonia in the rumen, which explains the relatively high initial concentration found before the concentrate was fed. Although in trial RM-A15 roughage was also included in the morning feed, this consisted of maize silage, which in the dry matter contains only about one-third of the soluble nitrogen present in prewilted grass silage (Veen, 1984). Wohlt et al. (1976a) found a peak in the concentration of ammonia 30 to 90 minutes after concentrate and hay were fed.

When the concentrate with rapidly degradable protein was fed, all trials showed a higher peak concentration than that recorded for a concentrate with slowly degradable protein. The highest average concentration of ammonia recorded for the ration with rapidly degradable protein varied from 10 to $12.5 \mathrm{mmol} / \mathrm{l}$ and for the slowly degradable protein from 4 to $8 \mathrm{mmol} / \mathrm{l}$. In comparing the maximum concentrations of ammonia recorded for the various trials one must bear in mind that the concentrates varied quite considerably in crude protein content. Only trials RM-B20 
and RM-B21 used the same concentrates (Table 1). The lowest average concentration registered after 3 hours was $1.5 \mathrm{mmol} / \mathrm{l}$ (Trial RM-B20). According to Satter \& Slyter (1974) the concentration at which maximum reuse of ammonia- $\mathrm{N}$ by bacteria takes place is approximately $3.5 \mathrm{mmol} / \mathrm{l}$. When prewilted grass silage is included in the ration, this concentration is easily attained, as shown by the results of trial RMA18.

The ration used in trial RM-A18 contained an ingredient which was treated with formaldehyde to protect it against breakdown of protein in the rumen and which represented $50 \%$ of the total protein. This produced a somewhat lower average concentration of ammonia than when ingredients were included which contained a large quantity of slowly degradable protein (Fig. $2 b$ ). When formaldehyde treated ingredients such as soya bean oil meal and rape-seed oil meal were included in the concentrate, the level of proteolysis in the rumen was significantly lower than for the original ingredients (Verité et al., 1977; Rooke et al., 1983).

In the light of the prevalent $\mathrm{pH}$, the rapid decline in the concentration of ammonia after the peak was recorded on a ration with rapidly fermentable protein can best be ascribed to utilization by bacteria, rather than to absorption through the rumen wall (Mahadevan et al., 1982). However, the quantity of protein being equal, the concentrate with rapidly fermentable protein is more likely to result in a shortage of nitrogen for the cellulolytic bacteria. These become activated only gradually after feeding, because they must first attach themselves to plant material (Mertens, 1977), and because the $\mathrm{pH}$ has not yet reached an optimum level for this activity. According to Huque \& Vestergaard Thomsen (1984) cellulolytic microbes prefer certain polypeptides, as a nitrogen source. The availability of these polypeptides about three hours after the intake of concentrate protein is more likely on a feed with slowly degradable protein. The significance of a concentrate protein that ferments slowly is that on the one hand more protein is allowed to reach the duodenum, while on the other hand the cellulolytic bacteria are provided with a sufficient quantity of nitrogen.

\section{Lactate}

The maximum concentration of both D- and L-lactate was registered after 30 and 45 minutes (Fig. 3). Malestein et al. (1984) found the peak to be somewhat later, namely after 1 to $1 \frac{1 / 2}{2}$ hours, but still prior to the point at which the $\mathrm{pH}$ reached its lowest level. In trial RM-B20 the concentration of lactate in cow Elze 64 remained at a relatively high level for a longer period when the concentrate with rapidly degradable protein was fed. This type of concentrate may be expected to lead to the formation of extra lactate, in comparison with a concentrate containing slowly degradable protein (Malestein et al., 1984). The principal lactate-forming microorganisms are known to grow more rapidly when there are proteins and amino acids present in solution in the rumen fluid, while the formation of lactate depends largely on the rate of growth (Counotte, 1981). We may however conclude from the results of trials RM-B20 and RM-B21 that the degradability of the concentrate protein does not influence either the course of the concentration of lactate or the maximum concentration, as long as the concentrate is consumed quickly. 


\section{Volatile fatty acids}

The breakdown of protein in the rumen produces not only ammonia but also carbon fragments which further fermentation breaks down into volatile fatty acids. In their research on wethers Hembry et al. (1975) found that a smaller quantity of all the fatty acids was produced when the slowly fermentable zein was fed, in comparison with soya bean oil meal and casein. The experimental treatment had the least effect on the concentration of butyric acid. In their work with sheep Leroy \& Zelter (1970) found little change in the concentration of the volatile fatty acids in the rumen, even when ingredients were fed which had been treated with tannins to reduce fermentation in the rumen. They did, however, register a lower concentration of butyric acid when ingredients treated with tannins were fed. Hembry et al. (1975) found that when proteins with varying solubility in vitro were fed, the rate of production of butyric acid remained approximately the same. Wohlt et al. (1976b) found that when proteins of high and low solubility were compared, the variations in the concentration of the volatile fatty acids could not be ascribed to differences in solubility as such, but were determined by the amino acid pattern of the soluble proteins.

The results of trials RM-B21 and RM-B22 showed that feeding concentrates with slowly degradable protein produces lower concentrations of iso-butyric acid, isovaleric acid and valeric acid in the rumen fluid. Verite \& Journet (1977) and Verité et al. (1977) found that the share of these fatty acids in the sum total of volatile fatty acids declined when formaldehyde-treated ingredients were fed. The precursors of these fatty acids are the amino acids valine, isoleucine and leucine. Thus less of these fatty acids are produced when less protein is broken down in the rumen. The branched chain fatty acids are essential growth factors for the cellulolytic bacteria, in particular Ruminococcus spp. (Teather et al., 1980). Thus it would seem inadvisable to slow down the proteolysis of the ration protein too much, in this case by treating it with formaldehyde. On the other hand, there might be some advantage in a more gradual production of these volatile fatty acids since, as we have seen above, the activity of the cellulolytic bacteria does not really get under way until several hours after feeding.

When the concentrate with slowly fermentable protein was fed, there was a significant shift in the ratio of acetate to propionate (Table 3). A large number of investigations have revealed positive correlations between the acetate/propionate ratio and the fat content of the milk. The latter was said to be negatively linked to the propionate proportion of the volatile fatty acids rather than positively to the acetic acid portion (McCullough, 1966; Storry \& Rooke, 1966). Since in trials RM-B21 and BM-B22 the butyric acid portion was at all sampling times higher when a concentrate with slowly degradable protein was fed, it can be concluded that this type of concentrate has a favourable effect on the synthesis of milk fat.

One explanation for the shift in the ratios of the fatty acids may be the fact that, under the influence of bacterial fermentation, proteins give rise to the formation of relatively more propionate. According to Demeyer \& Van Nevel (1979) net production of acetate and propionate from the in vitro incubation of the soluble protein casein was in a ration of 1.44 . 
The significance of a concentrate with slowly degradable protein would seem to lie in the stabilization of the rumen fermentation, which results in less extreme variations in concentrations in the rumen fluid after feeding. As a result of a less abundant fermentation of the protein, there is less displacement of cellulolytic bacteria by amylolytic. This effect will be even more pronounced when not only the protein but also the carbohydrate fraction is broken down more slowly. According to Mould \& Ørskov (1983), cellulolytic activity in the rumen can temporarily come to a complete halt if after a large quantity of concentrates is fed the $\mathrm{pH}$ for a time drops below the level of 6 .

Because where protein is fermented slowly ammonia, peptides and branched chain volatile fatty acids are released more gradually, these essential growth factors for the cellulolytic bacteria are available for many hours after feeding. As a result the degradation of cell walls takes place more gradually, which has a favourable influence on the ratio of acetic acid to propionic acid. This stabilization of the rumen fermentation can probably also be obtained by more frequent feeding. The results noted for cow Elze 64, who had such a slow feed intake, also point in this direction.

Measurements of various blood parameters would probably show whether the higher fat content of the milk and the higher milk production which we registered in various feeding trials with slowly degradable concentrate protein are exclusively the result of an altered rumen fermentation, or are also due to factors affecting the intermediary metabolism.

\section{References}

Bakker, Y. Tj. \& W. A. G. Veen, 1977. De benutting van eiwitten met uiteenlopende oplosbaarheid bij melkvee. Jaarverslag CLO-Instituut voor de Veevoeding 'De Schothorst': 38-40.

Bakker, Y. Tj. \& W. A. G. Veen, 1980. Tweede proef omtrent de invloed van de bestendigheid van het krachtvoereiwit op diverse produktiekenmerken van hoogproduktieve melkkoeien. Jaarverslag CLO-Instituut voor de Veevoeding 'De Schothorst': 44-45.

Bakker, Y. Tj., W. A. G. Veen \& J. P. Cornelissen, 1981. Derde proef omtrent de invloed van de bestendigheid van het krachtvoereiwit op verschillende produktiekenmerken van hoogproduktieve melkkoeien. Jaarverslag CLO-Instituut voor de Veevoeding 'De Schothorst': 36-38.

Bakker, Y. Tj., J. P. Cornelissen \& W. A. G. Veen, 1982. Vierde voederproef met bestendig eiwit voor melkvee. Jaarverslag CLO-Instituut voor de Veevoeding 'De Schothorst': 39-41.

Bakker, Y. Tj. \& W. A. G. Veen, 1983. Vijfde voederproef met bestendig eiwit voor melkvee in de stalperiode. Jaarverslag CLO-Instituut voor de Veevoeding 'De Schothorst': 43-44.

Bakker, Y. Tj., W. A. G. Veen \& J. P. Cornelissen, 1984. Meer of minder eiwit en bestendiger of onbestendiger eiwit voor hoogproduktieve verse koeien. Jaarverslag CLO-Instituut voor de Veevoeding 'De Schothorst': 49-52.

Baxter, H. D., M. J. Montgomery, D. R. Waldo \& J. R. Owen, 1983. Effect of method of feeding protein and protein insolubility on milk production by Jersey cows. Journal of Dairy Science 66: 20932099.

Counotte, G. H. M., 1981. Regulation of lactate metabolism in the rumen. Thesis, State University of Utrecht.

Crooker, B. A., C. J. Sniffen, W. H. Hoover \& L. L. Johnson, 1978. Solvents for soluble nitrogen measurements in feedstuffs. Journal of Dairy Science 61: 437-447.

Demeyer, D. \& C. Van Nevel, 1979. Protein fermentation and growth by rumen microbes. Annales des Recherches Vétérinaires 10: 277-279. 
Dennison, C. \& A. M. Philips, 1983. Balancing the duodenal amino acid supply in ruminants with practical feed ingredients. South African Journal of Animal Science 13: 229-235.

Erdman, R. A. \& J. H. Vandersall, 1983. Effect of rumen protein degradability on milk yield of dairy cows in early lactation. Journal of Dairy Science 66: 1873-1880.

Folman, Y., H. Neumark, M. Kaim \& W. Kaufmann, 1981. Performance, rumen and blood metabolites in high-yielding cows fed varying protein percents and protected soybean. Journal of Dairy Science 64: $759-768$.

Grummer, R. R. \& J. H. Clark, 1980. Effect of nitrogen solubility on milk yield, milk composition and ruminal degradation of protein. Journal of Dairy Science 63: Suppl. 1: 139.

Hembry, F. G., W. H. Pfander \& R. L. Preston, 1975. Utilization of nitrogen from soybean meal, casein, zein and urea by mature sheep. Journal of Nutrition 105: 267-273.

Huque, Q. Md. E. \& K. Vestergaard Thomsen, 1984. Source of nitrogen for rumen microbes. Acta Agriculturae Scandinavica 34: 26-32.

Kaufmann, W. \& W. Lüpping, 1979a. Zum Einfluss von Protected Protein und HMM-Ca auf die Leistung von Milchkühen. Zeitschrift für Tierphysiologie, Tierernährung und Futtermittelkunde 41: 202217.

Kaufmann, W. \& W. Lüpping, 1979b. Zum Wirkung von geschütztem Eiweiss und geschütztem Methionin in praktischen Fütterungsversuchen. Zeitschrift für Tierphysiologie, Tierernährung und Futtermittelkunde 42: 26.

Kaufmann, W., K. H. Lotthammer \& W. Lüpping, 1982. Zum Einfluss eines verminderten Proteingehaltes der Ration (über Verwendung von geschütztem Protein) auf Milchleistung und einige Blutparameter als Kennzeichen der Leberbelastung. Zeitschrift für Tierphysiologie, Tierernährung und Futtermittelkunde 47: 85-101.

Kung, L., J. T. Huber \& L. D. Satter, 1983. Influence of nonprotein nitrogen and protein of low rumen degradability on nitrogen flow and utilization in lactating dairy cows. Journal of Dairy Science 66: 1863-1872.

Leroy, F. \& S. Z. Zelter, 1970. Protection des protéines alimentaires contre la désamination bactérienne au niveau du rumen, II. Etudes in vivo sur moutons fistulés. Annales de Biologie animale, Biochimie, Biophysique 10: 401-412.

Mahadevan, S., F. D. Sauer, J. D. Erfle, R. M. Teather \& P. M. Morse, 1982. Changes in ammonia concentration, bacterial counts, $\mathrm{pH}$ and volatile fatty acid concentration in rumen of cows fed alfalfa hay or concentrate: urea-corn silage. Canadian Journal of Animal Science 62: 249-258.

Majdoub, A., G. T. Lane \& T. E. Aitchison, 1978. Milk production response to nitrogen solubility in dairy rations. Journal of Dairy Science 61: 59-65.

Malestein, A., A. Th. van 't Klooster, G. H. M. Counotte \& R. A. Prins, 1981. Concentrate feeding and ruminal fermentation. 1 . Influence of the frequency of feeding concentrates on rumen acid composition, feed intake and milk production. Netherlands Journal of Agricultural Science 29: 239-248.

Malestein, A., A. Th. van 't Klooster, R. A. Prins \& G. H. M. Counotte, 1984. Concentrate feeding and ruminal fermentation. 3. Influence of concentrate ingradients on $\mathrm{pH}$, on DL-lactic acid concentration in rumen fluid of dairy cows and on dry matter intake. Netherlands Journal of Agricultural Science 32: 9-21.

McCarthy, R. D., G. A. Porter \& L. C. Griel, 1968. Bovine ketosis and depressed fat test in milk: A problem of methionine metabolism and serum lipoprotein aberration. Journal of Dairy Science 51: 459-462.

McCullough, M. E., 1966. Relationship between rumen fluid volatile fatty acids and milk fat percentage and feed intake. Journal of Dairy Science 49: 896-898.

Mertens, D. R., 1977. Importance and measurement of protein insolubility in ruminant diets. Proceedings of the Georgia Nutrition Conference: $30-43$.

Mould, F. L. \& E. R. Ørskov, 1983. Manipulation of rumen fluid $\mathrm{pH}$ and its influence on cellulolysis in sacco, dry matter degradation and the rumen microflora of sheep offered either hay or concentrate. Animal Feed Science \& Technology 10: 1-14.

Oldham, J. D., 1980. Amino acid requirements for lactation in high-yielding dairy cows. In: W. Haresign (Ed.), Recent advances in animal nutrition, p. 33-65. Butterworths, London.

Oldham, J. D., W. H. Broster, D.J. Napper \& T. Smith, 1979a. Predicted and measured performance of 
Friesian cows fed on rations calculated to differ in rumen degradable protein and undegraded protein. Proceedings of the Nutrition Society 38: A128.

Oldham, J. D., W. H. Broster, D. J. Napper \& J. W. Siviter, 1979b. The effect of a low-protein ration on milk yield and plasma metabolites in Friesian heifers during early lactation. British Journal of Nutrition 42: 149-162.

Ørskov, E. R., G. W. Reid \& I. McDonald, 1981. The effects of protein degradability and food intake on milk yield and composition in cows in early lactation. British Journal of Nutrition 45: 547-555.

Phipps, R. H., R. F. Weller, T. Smith \& R. J. Fulford, 1981. Protein studies on maize silage as a basal ration for dairy cows. Journal of Agricultural Science, Cambridge 96: 283-290.

Rae R. C., J. R. Ingalls \& J. A. McKirdy, 1983. Response of dairy cows to formaldehyde-treated canola meal during early lactation. Canadian Journal of Animal Science 63: 905-916.

Rémond, B., C. Champredon, C. Decaen, R. Pion \& M. Journet, 1971. Influence d'un apport de DLméthionine à des vaches au début de la lactation sur la production laitière et la composition du sang. Annales de Biologie Animale, Biochimie, Biophysique 11: 455-469.

Rooke J. A., I. M. Brookes \& D. G. Armstrong, 1983. The digestion of untreated and formaldehydetreated soya-bean and rapeseed meals by cattle fed a basal silage diet. Journal of Agricultural Science, Cambridge 100: 329-342.

Satter, L. D. \& L. L. Slyter, 1974. Effect of ammonia concentration on rumen microbial protein production in vitro, British Journal of Nutrition 32: 199-208.

Storry, J. E. \& J. A. F. Rook, 1966. The relationship in the cow between milk-fat secretion and ruminal volatile fatty acids. British Journal of Nutrition 20: 217-228.

Teather, R. M., J. D. Erfle, R. J. Boila \& F. D. Sauer, 1980. Effect of dietary nitrogen on the rumen microbial population in lactating diary cattle. Journal of Applied Bacteriology 49:231-238.

Veen, W. A. G., 1984. Stikstof in ruwvoeders en de fermentatie in de pens. Landbouwkundig Tijdschrift 96(12): 25-28.

Verité, R. \& M. Journet, 1977. Utilisation des tourteaux traités au formol par les vaches laitières. II. Effects sur la production laitière du traitement des tourteaux et du niveau d'apport azoté au début de la lactation. Annales de Zootechnie 26: 183-205.

Verité, R., C. Poncet, S. Chabi \& R. Pion, 1977. Utilisation des tourteaux traités au formol par les vaches laitières. I. Aspects digestifs. Annales do Zootechnie 26: 167-181.

Wilson, P. N. \& P. J. Strachan, 1980. The contribution of undegraded protein to the protein requirements of dairy cows. In: W. Haresign (Ed.), Recent advances in animal nutrition, p. 99-188. Butterworths, London.

Wohlt, J. E., J. H. Clark \& F. S. Blaisdell, 1976a. Effect of sampling location, time, and method of concentration of ammonia nitrogen in rumen fluid. Journal of Dairy Science 59: 459-464.

Wohlt, J. E., C. J. Sniffen, W. H. Hoover, L. L. Johnson \& C. K. Walker, 1976b. Nitrogen metabolism in whethers as affected by dietary protein solubility and amino acid profile. Journal of Animal Science 42: $1280-1289$.

Wohlt, J. E., C. J. Sniffen \& W. H. Hoover, 1973. Measurement of protein solubility in common feedstuffs. Journal of Dairy Science 56: 1052-1057. 